\title{
Case Report: Sporadic Burkitt lymphoma misdiagnosed as dental abscess in a 15-year-old girl [version 1; peer review: 2
}

\section{approved]}

\author{
Marco Cabras (D1, Paolo G. Arduino1, Luigi Chiusa2, Roberto Broccoletti1, \\ Mario Carbone ${ }^{1}$ \\ ${ }^{1}$ Department of Surgical Sciences, Oral Medicine Section, CIR-Dental School, University of Turin, Turin, 10126, Italy \\ 2Pathology Unit, Città della Salute e della Scienza di Torino, Turin, 10126, Italy
}

V1 First published: 28 Sep 2018, 7:1567

https://doi.org/10.12688/f1000research.16390.1

Latest published: 28 Sep 2018, 7:1567

https://doi.org/10.12688/f1000research.16390.1

\section{Abstract}

Background: Burkitt lymphoma $(\mathrm{BL})$ is a non-Hodgkin's B-cell tumor that can be classified into three variants, based on clinical characteristics and epidemiology: endemic, human immunodeficiency-related and sporadic. Oral sporadic BL is quite an unusual entity, with the gastrointestinal trait being often the first site of appearance.

Clinical finding: A 15-year-old patient that presented a symptomatic swelling of the right maxilla, unsuccessfully treated as a primary endodontic disease, displaying solid tissue on CT scan, "starry sky" pattern on oral biopsy, multifocal bone and lymph node uptake on PET.

Diagnoses, interventions, and outcomes: A diagnosis of stage IV BL was formulated; Rituximab was then administered for three months according to Inter-B-NHL ritux 2010 protocol and CYM (cytarabine and methotrexate) chemotherapy. The patient was followed-up for three years, with no recurrence.

Conclusion: It is important for general dental practitioners to suspect a malignancy in the differential diagnosis of unresponsive odontogenic infections in young healthy patients.

\section{Keywords}

Burkitt lymphoma, dental abscess, oral cavity, paediatric

\section{Open Peer Review}

Approval Status

$\checkmark v$

1

2

version 1

28 Sep 2018

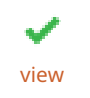

$\checkmark$

1. Cristiana Bellan ID, University of Siena,

Siena, Italy

\section{Mahmoud Rezk Abdelwahed Hussein (D),}

Assiut University, Assiut, Egypt

Any reports and responses or comments on the article can be found at the end of the article. 
Corresponding author: Marco Cabras (cabrasmarco300@gmail.com)

Author roles: Cabras M: Data Curation, Writing - Original Draft Preparation, Writing - Review \& Editing; Arduino PG: Methodology, Validation, Writing - Review \& Editing; Chiusa L: Data Curation, Resources; Broccoletti R: Supervision, Visualization; Carbone M:

Conceptualization, Formal Analysis, Supervision

Competing interests: No competing interests were disclosed.

Grant information: The author(s) declared that no grants were involved in supporting this work.

Copyright: (c) 2018 Cabras M et al. This is an open access article distributed under the terms of the Creative Commons Attribution License, which permits unrestricted use, distribution, and reproduction in any medium, provided the original work is properly cited.

How to cite this article: Cabras M, Arduino PG, Chiusa L et al. Case Report: Sporadic Burkitt lymphoma misdiagnosed as dental abscess in a 15-year-old girl [version 1; peer review: 2 approved] F1000Research 2018, 7:1567

https://doi.org/10.12688/f1000research.16390.1

First published: 28 Sep 2018, 7:1567 https://doi.org/10.12688/f1000research.16390.1 


\section{Introduction}

Burkitt lymphoma (BL) is a mature, aggressive high-grade B-cell non-Hodgkin's lymphoma, which occurs in three distinctive subtypes: endemic (African), human immunodeficiencyrelated and sporadic (nonendemic) ${ }^{1}$. Endemic BL, which was the first to be described as a "sarcoma" by Denis Burkitt in African children 60 years $\mathrm{ago}^{2}$, occurs mostly among six-yearold males of equatorial Africa and Papua New Guinea, mainly within the maxillofacial complex, with an estimated $50 \%$ of cases detected in jaws or facial bones. Sporadic BL is typically observed in Western countries, with a European incidence of 2.2 cases per million, affecting mostly young adult Caucasian males, frequently within the abdomen, particularly in the ileocecal trait ${ }^{1}$.

The oral cavity is rarely the first site of onset. In this report, we describe the peculiar case of an IV-stage BL arisen as a maxillary swelling in a 15-year-old girl, misdiagnosed at first as endodontic disease.

\section{Case report}

In November 2015, a healthy 15-year-old female was referred to our Department with chief complaint of dull pain on the permanent maxillary right second molar, on whom the general dental practitioner had already performed root canal treatment and administration of two grams of amoxicillin daily for one week, to no avail. Further questioning revealed an associated hypoesthesia of the right lower lip.

Conventional oral examination showed an overall swelling of the gingiva surrounding the painful teeth and extending to the right palatal mucosa (Figure 1), whereas no signs of oral disease could be detected in the lower lip. Orthopantomography (OPT) showed no signs of odontogenic disease, being completely unremarkable (Figure 2).
Due to the unreliability of OPT and the unresponsiveness to the combination of root canal and antibiotic treatments, a contrast-enhanced CT scan of the maxillo-facial district was urgently required, revealing solid tissue with high uptake in the right maxilla, with osteolysis and disruption of the floor of the right maxillary sinus (Figure 3).

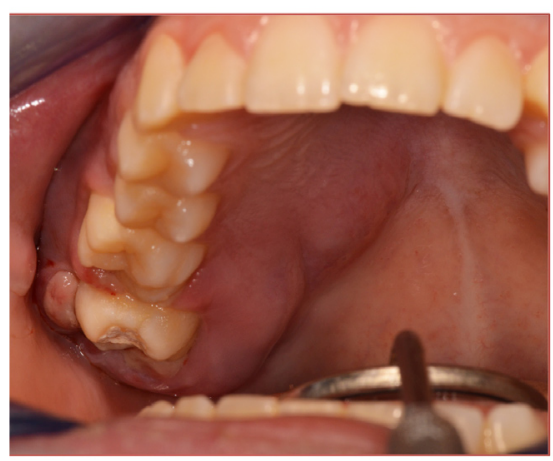

Figure 1. Intra-oral clinical aspect. Swelling of the right maxillary alveolar ridge, expanded to the right hard palate.

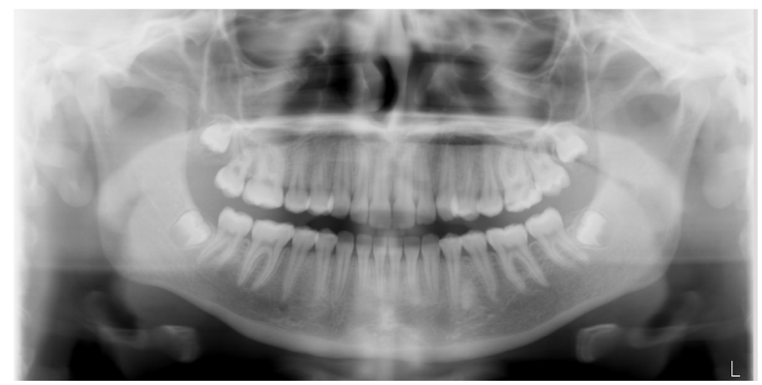

Figure 2. Ortopantomography, showing no evidence of any organic lesion in the oral and maxillofacial area.

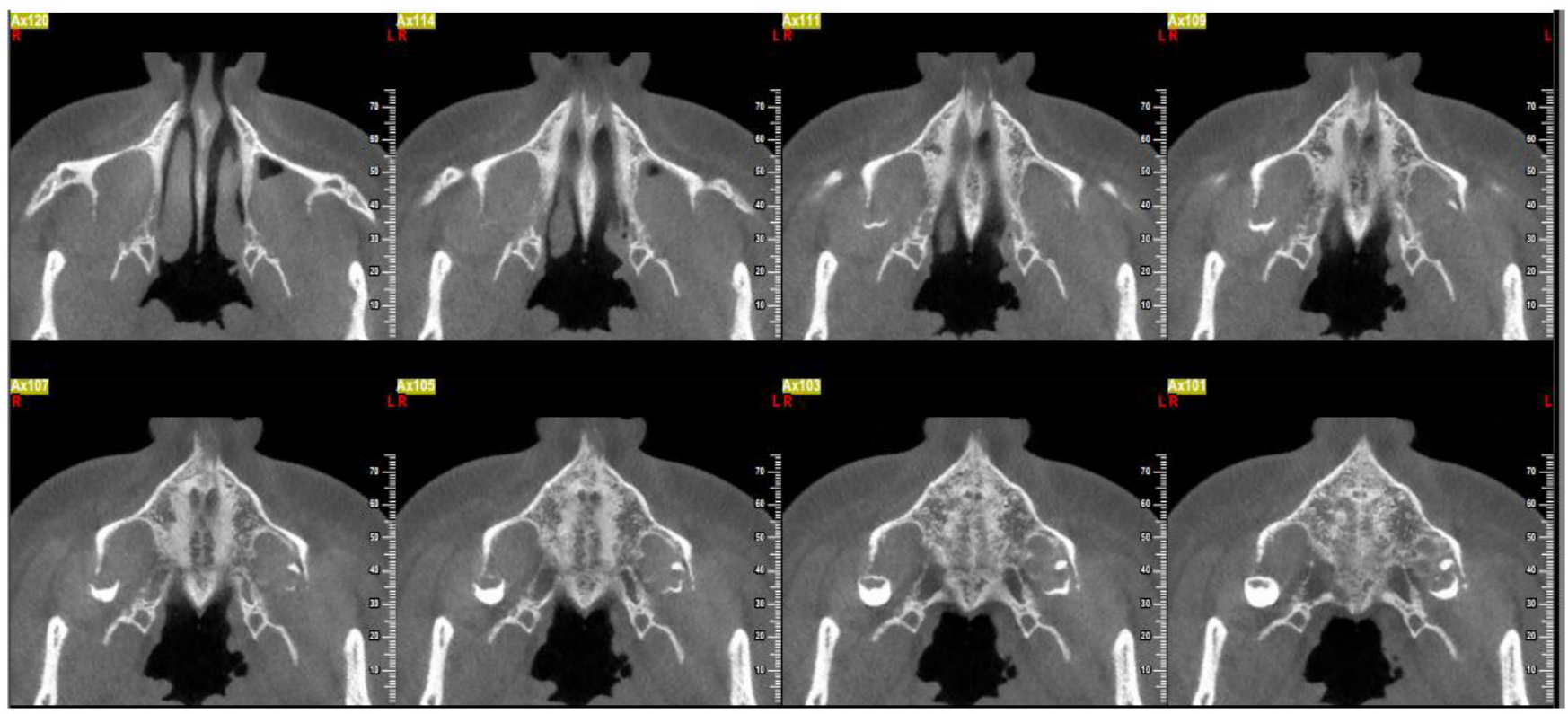

Figure 3. CT scan. Assial view showing solid mass in right maxilla causing destruction of the maxillary sinus floor 
A field mapping biopsy was conducted, collecting samples from gingiva, inter-radicular tissue from the extracted permanent maxillary right second molar, palatal bone and mucosa. Histology showed in each slide a diffuse infiltration of monomorphic, medium size cells with scarce basophilic cytoplasm, non-cleaved round nuclei, mitotically active with a high rate of spontaneous apoptosis (Figure 4a). Immunophenotyping revealed an abnormal B-lymphocyte population $(75 \%$ of cellular events), positive for CD20, with mild co-expression of CD10 c-Myc, and Immunoglobulin lambda light chains. Fluorescent in situ hybridization (FISH) revealed IgH/Myc translocation in $70 \%$ of the nuclei, being negative for IgH/BCL2 and IgH/BCL6 translocation. CISH staining for EBV-encoded RNA (EBER) transcript was widely positive (Figure 4b).

The young patient was referred to the Oncohaematology Paediatric Unit of the "Ospedale Infantile Regina Margherita", Turin, with a clinicopathological diagnosis of Burkitt Lymphoma.

Here, an 18F-FDG PET/CT was required, highlighting intense uptake in maxilla, shoulder blades, right humerus, dorsolumbar vertebrae and pelvis. Given the combination of clinical signs, microscopy findings and diagnostic imaging, a diagnosis of stage IV Burkitt lymphoma was formulated. The patient was treated with an association of Rituximab according to Inter-B-NHL ritux 2010 protocol and CYM (cytarabine and methotrexate) chemotherapy, between December 2015 and March 2016.

In May 2016, a PET/CT scan showed a complete remission of the disease; clinical oral examination showed the com-

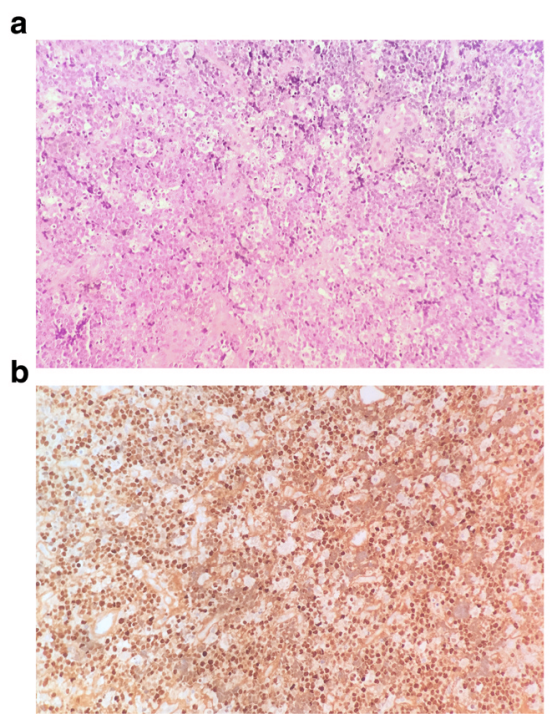

Figure 4. Histopathological examination of the sample.

(A) Hematoxylin \& eosin 20x revealing "Starry-sky" pattern from pleomorphic and highly apoptotic lymphocytes and macrophages; (B) EBER 20x in situ hybridization positive to EBV-encoded RNA. plete remission of gingiva-palatal enlargement. Since then, the currently 18-year-old patient appears to be in good health.

\section{Discussion}

Oral sporadic Burkitt lymphoma (sBL) is a rare clinical entity among children, with few case reports published to date ${ }^{3-13}$. To the best of our knowledge, this is the first detailed report of oral sBL in a teenage patient in Italy.

Case-series available worldwide ${ }^{14-18}$ show an infrequent involvement of the mouth as the first site, accounting for $3 \%{ }^{14,15}$, $9.5 \%^{16}$, up to $16 \%^{17,18}$ of all sBL. Clinically, oral sBL acts as a fast growing, rapidly expanding tumor, which may cause dull, toothache-like pain, teeth malposition, occlusal precontact with subsequent difficulty in chewing and open-bite ${ }^{6}$; in some cases sudden teeth loosening can be elicited ${ }^{6,11}$.

Such behavior can easily be mistaken for an odontogenic disease, leading to the general dental practitioner (GDP) to administer antibiotics and perform unnecessary procedures, such as root canal treatments of the teeth closest to the swollen or painful area, as the presented case and a previous report have shown ${ }^{3}$, causal periodontal treatment ${ }^{11}$ or even teeth extractions $^{9,10}$. Moreover, when tonsil is the primary site, dysphagia and obstructive sleep apnoea may occur ${ }^{5,12}$.

Panoramic radiograph can be either unremarkable, as in our case and a similar report ${ }^{4}$, or can reveal an ill-defined isolated ${ }^{7,9}$ or multifocal ${ }^{11}$ radiolucency with loss of lamina dura and periodontal ligament ${ }^{6,7,9,13}$, sometimes displaying a worrisome "floating teeth" appearance ${ }^{6,7}$. Thus, cervicofacial CT is mandatory to properly assess the degree of disruption of the cortical bone and the status of the neighbouring naso-orbital areas ${ }^{5,8,11}$. On the other hand, an 18-FDG PET may be needed either to fulfil the diagnostic work-up when suspecting a widespread lymphoma $a^{5,10}$, or used as a monitoring tool, especially in the first 12 months after diagnosis, where relapse can be more frequently encountered ${ }^{12}$. Ultimately, an in-depth histologic analysis, comprehensive of immunophenotyping showing CD20 positive clones and FISH revealing of $\mathrm{IgH} / \mathrm{Myc}$ translocation will be the key to unravel the differential diagnosis with a wide range of diseases which may share overlapping symptoms and clinicoradiological signs, such as osteomyelitis, benign odontogenic epithelial neoplasms, other types of lymphomas, Langerhans cell histiocytosis, Ewing's sarcoma, osteosarcoma, chondrosarcoma, neurosarcoma and fibrosarcoma ${ }^{4,7,10}$

Being a rapidly growing tumor with a very high replicative activity, BL proves to be particularly sensitive to cytotoxic chemotherapeutic agents, in particular in a polychemotherapy regimen alongside rituximab, an anti-CD20 monoclonal antibody responsible of a further increase of the five-years survival rate, which can amount up to $90-100 \%$ or early stages s $^{1,8,19}$.

Therefore, since prognosis is closely related to the earliness of diagnosis, the specialists and GDPs should consider the 
possibility of a BL in case of rapid swelling of the jaws in young healthy individuals, especially if nonresponsive to traditional antibiotic therapy.

\section{Consent}

An informed consent form was signed by the patient's mother, in order to obtain permission for photo usage and for the use and publication of the young patient's data.

\section{Data availability}

All data underlying the results are available as part of the article and no additional source data are required.

\section{Grant information}

The author(s) declared that no grants were involved in supporting this work.
1. Dozzo M, Carobolante F, Donisi PM, et al:: Burkitt lymphoma in adolescents and young adults: management challenges. Adolesc Health Med Ther. 2016; 8: $11-29$.

PubMed Abstract | Publisher Full Text | Free Full Text

2. BURKITT D: A sarcoma involving the jaws in African children. Br J Surg. 1958; 46(197): 218-23.

PubMed Abstract | Publisher Full Text

3. Ardekian L, Peleg M, Samet N, et al:: Burkitt's lymphoma mimicking an acute dentoalveolar abscess. J Endod. 1996; 22(12): 697-8.

PubMed Abstract | Publisher Full Text

4. Tsui SH, Wong MH, Lam WY: Burkitt's lymphoma presenting as mandibular swelling--report of a case and review of publications. Br J Oral Maxillofac Surg. 2000; 38(1): 8-11.

PubMed Abstract | Publisher Full Text

5. Banthia V, Jen A, Kacker A: Sporadic Burkitt's lymphoma of the head and neck in the pediatric population. Int J Pediatr Otorhinolaryngol. 2003; 67(1): 59-65. PubMed Abstract | Publisher Full Text

6. Jan A, Vora K, Sándor GK: Sporadic Burkitt's lymphoma of the jaws: the essentials of prompt life-saving referral and management. J Can Dent Assoc. 2005; 71(3): 165-8.

PubMed Abstract

7. Patil K, Mahima VG, Jayanth BS, et al:: Burkitt's lymphoma in an Indian girl: a case report. J Indian Soc Pedod Prev Dent. 2007; 25(4): 194-9. PubMed Abstract | Publisher Full Text

8. Valenzuela-Salas B, Dean-Ferrer A, Alamillos-Granados FJ: Burkitt's lymphoma: a child's case presenting in the maxilla. Clinical and radiological aspects. Med Oral Patol Oral Cir Bucal. 2010; 15(3): e479-82.

PubMed Abstract | Publisher Full Text

9. Pereira CM, Lopes AP, Meneghini AJ, et al:: Burkitt's lymphoma in a young Brazilian boy. Malays J Pathol. 2010; 32(1): 59-64. PubMed Abstract

10. Bilodeau E, Galambos C, Yeung A, et al:: Sporadic Burkitt lymphoma of the jaw: case report and review of the literature. Quintessence Int. 2012; 43(4): 333-6. PubMed Abstract
11. Padmanabhan MY, Pandey RK, Kumar A, et al.: Dental management of a pediatric patient with Burkitt lymphoma: a case report. Spec Care Dentist. 2012; 32(3): 118-23.

PubMed Abstract | Publisher Full Text

12. Toader $\mathrm{C}$, Toader $\mathrm{M}$, Stoica $\mathrm{A}$, et al:: Tonsillar lymphoma masquerading as obstructive sleep apnea - pediatric case report. Rom J Morphol Embryol. 2016; 57(2 Suppl): 885-891. PubMed Abstract

13. Ugar DA, Bozkaya S, Karaca I, et al:: Childhood craniofacial Burkitt's lymphoma presenting as maxillary swelling: report of a case and review of literature. J Dent Child (Chic). 2006; 73(1): 45-50 PubMed Abstract

14. Mbulaiteye SM, Biggar RJ Bhatia K, et al.: Sporadic childhood Burkitt lymphoma incidence in the United States during 1992-2005. Pediatr Blood Cancer. 2009 53(3): 366-70

PubMed Abstract | Publisher Full Text | Free Full Text

15. Sandlund JT, Fonseca T, Leimig T, et al.: Predominance and characteristics of Burkitt lymphoma among children with non-Hodgkin lymphoma in northeastern Brazil. Leukemia. 1997; 11(5): 743-6. PubMed Abstract | Publisher Full Text

16. Ramanathan A, Mahmoud HA, Hui LP, et al.: Oral extranodal non Hodgkin's lymphoma: series of forty two cases in Malaysia. Asian Pac J Cancer Prev. 2014; 15(4): 1633-7.

PubMed Abstract | Publisher Full Text

17. Ertem U, Duru F, Pamir A, et al.: Burkitt's lymphoma in $\mathbf{6 3}$ Turkish children diagnosed over a 10 year period. Pediatr Hematol Oncol. 1996; 13(2): 123-34. PubMed Abstract | Publisher Full Text

18. Bi CF, Tang Y, Zhang WY, et al: Sporadic Burkitt lymphomas of children and adolescents in Chinese: a clinicopathological study of $\mathbf{4 3}$ cases. Diagn Pathol. 2012; 7: 72 .

PubMed Abstract | Publisher Full Text | Free Full Text

19. Dunleavy K, Little RF, Wilson WH: Update on Burkitt Lymphoma. Hematol Oncol Clin North Am. 2016, 30(6): 1333-1343.

PubMed Abstract | Publisher Full Text 


\section{Open Peer Review}

\section{Current Peer Review Status:}

\section{Version 1}

Reviewer Report 18 February 2020

https://doi.org/10.5256/f1000research.17904.r54889

(C) 2020 Abdelwahed Hussein $\mathbf{M}$. This is an open access peer review report distributed under the terms of the Creative Commons Attribution License, which permits unrestricted use, distribution, and reproduction in any medium, provided the original work is properly cited.

\section{Mahmoud Rezk Abdelwahed Hussein}

Department of Pathology, Assiut University, Assiut, Egypt

This is a well written paper that presents a very interesting case report that concisely describes and addresses a rare clinicopathologic entity in the realm of lymphoma, in particular oral lymphomatous proliferation. The case details were presented clearly and concisely. The relevant literature and studies were nicely summarized and addressed. All in all, I support a decision "to accept".

Is the background of the case's history and progression described in sufficient detail? Yes

Are enough details provided of any physical examination and diagnostic tests, treatment given and outcomes?

Yes

Is sufficient discussion included of the importance of the findings and their relevance to future understanding of disease processes, diagnosis or treatment?

Yes

Is the case presented with sufficient detail to be useful for other practitioners? Yes

Competing Interests: No competing interests were disclosed.

Reviewer Expertise: Molecular pathology

I confirm that I have read this submission and believe that I have an appropriate level of expertise to confirm that it is of an acceptable scientific standard. 
Reviewer Report 11 December 2018

\section{https://doi.org/10.5256/f1000research.17904.r40653}

(C) 2018 Bellan C. This is an open access peer review report distributed under the terms of the Creative Commons Attribution License, which permits unrestricted use, distribution, and reproduction in any medium, provided the original work is properly cited.

\section{Cristiana Bellan}

Department of Medical Biotechnologies, University of Siena, Siena, Italy

The Authors describe a case of Sporadic Burkitt lymphoma in an adolescent patient with an "non conventional" oral presentation. They well describe the imaging appearence, the morphology and immunophenotyping as well as molecular characteristics of this entity, highlinting the importance of the differential diagnosis in the oral pathology in young patients.

Is the background of the case's history and progression described in sufficient detail? Yes

Are enough details provided of any physical examination and diagnostic tests, treatment given and outcomes?

Yes

Is sufficient discussion included of the importance of the findings and their relevance to future understanding of disease processes, diagnosis or treatment?

Yes

Is the case presented with sufficient detail to be useful for other practitioners?

Yes

Competing Interests: No competing interests were disclosed.

I confirm that I have read this submission and believe that I have an appropriate level of expertise to confirm that it is of an acceptable scientific standard. 
The benefits of publishing with F1000Research:

- Your article is published within days, with no editorial bias

- You can publish traditional articles, null/negative results, case reports, data notes and more

- The peer review process is transparent and collaborative

- Your article is indexed in PubMed after passing peer review

- Dedicated customer support at every stage

For pre-submission enquiries, contact research@f1000.com 